\title{
Variability in runoff fluxes of dissolved and particulate carbon and nitrogen from two watersheds of different tree species during intense storm events
}

\author{
Mi-Hee Lee ${ }^{1}$, Jean-Lionel Payeur-Poirier ${ }^{2}$, Ji-Hyung Park ${ }^{3}$, and Egbert Matzner ${ }^{1}$ \\ ${ }^{1}$ Department of Soil Ecology, University of Bayreuth (BayCEER), Dr.-Hans-Frisch-Straße 1-3, Bayreuth, 95448, Germany \\ ${ }^{2}$ Department of Hydrology, University of Bayreuth (BayCEER), Universitätsstrasse 30, Bayreuth, 95447, Germany \\ ${ }^{3}$ Department of Environmental Science and Engineering, Ewha Womans University, Ewhayeodae-gil 52, Seodaemun-gu, \\ Seoul, 03760, South Korea
}

Correspondence to: Egbert Matzner (egbert.matzner@uni-bayreuth.de)

Received: 15 March 2016 - Published in Biogeosciences Discuss.: 13 May 2016

Revised: 30 August 2016 - Accepted: 1 September 2016 - Published: 29 September 2016

\begin{abstract}
Heavy storm events may increase the amount of organic matter in runoff from forested watersheds as well as the relation of dissolved to particulate organic matter. This study evaluated the effects of monsoon storm events on the runoff fluxes and on the composition of dissolved $(<0.45 \mu \mathrm{m})$ and particulate $(0.7 \mu \mathrm{m}$ to $1 \mathrm{~mm})$ organic carbon and nitrogen (DOC, DON, POC, PON) in a mixed coniferous/deciduous (mixed watershed) and a deciduous forested watershed (deciduous watershed) in South Korea. During storm events, DOC concentrations in runoff increased with discharge, while DON concentrations remained almost constant. DOC, $\mathrm{DON}$ and $\mathrm{NO}_{3}-\mathrm{N}$ fluxes in runoff increased linearly with discharge pointing to changing flow paths from deeper to upper soil layers at high discharge, whereas nonlinear responses of POC and PON fluxes were observed likely due to the origin of particulate matter from the erosion of mineral soil along the stream benches. The integrated $\mathrm{C}$ and $\mathrm{N}$ fluxes in runoff over the 2-month study period were in the order of $\mathrm{DOC}>\mathrm{POC}$ and $\mathrm{NO}_{3}-\mathrm{N}>\mathrm{DON}>\mathrm{PON}$. The integrated DOC fluxes in runoff during the study period were much larger at the deciduous watershed $\left(16 \mathrm{~kg} \mathrm{Cha}^{-1}\right)$ than at the mixed watershed $\left(7 \mathrm{kgCha}^{-1}\right)$, while the integrated $\mathrm{NO}_{3}-\mathrm{N}$ fluxes were higher at the mixed watershed $\left(5.2 \mathrm{~kg} \mathrm{Nha}^{-1}\right)$ than at the deciduous watershed $\left(2.9 \mathrm{~kg} \mathrm{Nha}^{-1}\right)$. The latter suggests a larger $\mathrm{N}$ uptake by deciduous trees. Integrated fluxes of POC and PON were similar at both watersheds. The composition of organic matter in soils and runoff indicates that the contribution of near-surface flow to runoff was larger
\end{abstract}

at the deciduous than at the mixed watershed. Our results demonstrate different responses of particulate and dissolved $\mathrm{C}$ and $\mathrm{N}$ in runoff to storm events as a combined effect of tree species composition and watershed specific flow paths.

\section{Introduction}

As much of the dissolved organic matter (DOM) in aquatic systems originates from soil-derived organic matter, the export of terrestrial carbon $(\mathrm{C})$ and nitrogen $(\mathrm{N})$ into aquatic environments is a primary link between these systems (Bauer and Bianchi, 2011; Bianchi, 2011; Camino-Serrano et al., 2014; Canham et al., 2012). The export of terrestrial C and $\mathrm{N}$ occurs in the form of dissolved and particulate organic carbon and nitrogen (DOC, DON, POC, PON). Particulate organic matter can be operationally classified into fine ( 0.1 to $63 \mu \mathrm{m}$ ) and coarse (63 $\mu \mathrm{m}$ to $2 \mathrm{~mm}$ ) fractions (Richey, 2005). The export of POC was in some cases the major $\mathrm{C}$ export in stream (Dhillon and Inamdar, 2013; Jung et al., 2012; Kim et al., 2010; Lloret et al., 2013). In contrast, DOC was reported as the dominant organic $\mathrm{C}$ form in a temperate headwater catchment (Johnson et al., 2006), a tropical rainforest catchment (Bass et al., 2011), and for several large tropical watersheds such as Amazon, Orinoco, Parana, and Mengong (Lloret et al., 2013). 
In regions with seasonally large differences in precipitation, most of the annual organic $\mathrm{C}$ export from forested watershed to steams is driven by heavy storm events with cyclones and hurricane (Dhillon and Inamdar, 2013; Lloret et al., 2013). Such conditions are pronounced in the Korean Peninsula, where the monsoon season (Jeong et al., 2012; Kim et al., 2010) represented 52 and $83 \%$ of the annual DOC and POC runoff fluxes. During storm events, a change in hydrological flow paths in watersheds has often been observed from deeper to upper soil layers (Bass et al., 2011; Sanderman et al., 2009; Singh et al., 2014). Surface flowinducing storm events can alter the fluxes and concentrations of DOC and POC in runoff by shifting preferential flows through macropores, surface runoff, and lateral flow (Katsuyama and Ohte, 2002; Kim et al., 2010; McGlynn and McDonnell, 2003).

In the case of organic $\mathrm{N}$ export, DON was the major form of $\mathrm{N}$ in runoff from pristine forested watersheds (AlvarezCobelas et al., 2008; Frank et al., 2000; Kaushal and Lewis, 2003; Pellerin et al., 2006; Yates and Johnes, 2013). Only few data are available on the partitioning of DON and PON fluxes in runoff from forested watersheds, like Inamdar et al. (2015). They reported that particulate N composed 39$87 \%$ of the storm event $\mathrm{N}$ export. The question remains open of whether organic $\mathrm{N}$ in runoff - either dissolved or particulate - from forested watersheds behaves similar to organic $\mathrm{C}$ or not. Some studies reported that concentrations of DON and DOC correlated strongly (von Schiller et al., 2015), but weak relationships were also found (Singh et al., 2015).

Considering an effect of watershed characteristic, tree species might influence the export of DOM from forested watersheds. DOM from coniferous litter generally comprises more refractory (e.g., hydrophobic acid, lignin) and aromatic compounds and a relatively larger proportion of high molecular weight compounds than DOM from deciduous litter. It is also more acidic than DOM from deciduous litter (Don and Kalbitz, 2005; Hansson et al., 2011; Kiikkilä et al., 2013). Moreover, higher DOC and DON concentrations were found in oak, beech, and silver birch forest floors compared to Norway spruce, Douglas fir, and Scots pine (Smolander and Kitunen, 2011; Trum et al., 2011). Amiotte-Suchet et al. (2007) found higher annual DOC concentrations and fluxes in runoff at a deciduous forested watershed than at a watershed dominated by coniferous species.

As a result of global warming, heavy storm events have occurred more frequently and become stronger in recent decades (IPCC, 2013). Furthermore, forest management, namely the selection of tree species, might influence the export of organic matter from forested watersheds. Understanding the influence of both drivers is needed for a better prediction of the link between terrestrial and aquatic ecosystems and to support an efficient downstream water quality management. The goal of this study was thus to investigate the influence of tree species and heavy storm events on the fluxes of dissolved and particulate forms of $\mathrm{C}$ and $\mathrm{N}$ from a mixed coniferous/deciduous and a deciduous forested watershed in South Korea during the 2013 monsoon season.

\section{Materials and methods}

\subsection{Study area and site}

The Lake Soyang basin area (Fig. 1) is located in the upstream region of the Han River, which is the main source of drinking water for about 23 million citizens of South Korea (Lee et al., 2013; Park et al., 2010). The average annual temperature of the Lake Soyang watershed in western Gangwon province is $11^{\circ} \mathrm{C}$ with monthly average temperature ranging from $-5^{\circ} \mathrm{C}$ in January to $24^{\circ} \mathrm{C}$ in August (Korean meteorological administration, www.kma.go.kr). Annual precipitation ranges from 1200 to $1500 \mathrm{~mm}$ and the summer monsoon usually accounts for 50 to $60 \%$ of the annual precipitation (Park et al., 2010; Seo et al., 2011). Korean mountainous forests are mostly composed of deciduous forests representing $47 \%$ of the total forested area (38\% coniferous forest, $12 \%$ mixed coniferous and deciduous forest) and most of the broadleaved forests of South Korea are distributed within the Gangwon province (Korea forest research institute, 2013).

The mixed coniferous/deciduous forested watershed (mixed watershed; Fig. 1) is located in Seohwa, the Gangwon province $\left(38^{\circ} 12^{\prime} \mathrm{N}, 128^{\circ} 11^{\prime} \mathrm{E} ; 368\right.$ to $682 \mathrm{~m}$ above sea level). The area of the mixed watershed (Table 1) is 15.6 ha with 6.1 ha of coniferous forest (39\%) and 9.5 ha of deciduous forest $(61 \%)$. Two research plots as one in the coniferous part (MC plot) and the other one in the deciduous part (MD plot) were established. The slope of the mixed watershed as obtained from a digital elevation model ranges from 4.0 to $41^{\circ}$ with an average of $28^{\circ}$. The lower part of the mixed watershed is dominated by coniferous species, including Larix kaempferi (Lamb.) Carr. (Japanese larch) and Pinus densiflora Siebold \& Zucc. (Japanese red pine). The upper part of the mixed watershed is dominated by deciduous species, such as Juglans mandshurica Maxim. (Manchurian walnut), Acer pictum subsp. mono (Maxim.) H.Ohashi (Mono maple), Quercus dentata Thunb. (Daimyo oak), Tilia amurensis Kom. (Lime tree), and Ulmus davidiana var. japonica (Rehder) Nakai (Japanese elm).

The slope direction of the coniferous part at the mixed watershed is towards the MD plot. Lateral flow from the coniferous part to the MD plot can only influence deeper soil solution characteristics as near-surface flow was never observed. Our data (see results) indicate significant quality differences of soil solutions between the MD and MC plots which suggest only a minor influence on soil solution chemistry at the MD plot from lateral flows. Furthermore, the quality parameters of soil solutions at the MD plot were similar to those of the DD plot, the latter being not influenced by lateral flows from coniferous sites. Thus, it is unlikely that the MC plot did affect the MD plot. 
Table 1. Tree species composition and geomorphological characteristics of the studied forested watersheds.

\begin{tabular}{llrrr}
\hline Watershed & Major tree species & $\begin{array}{r}\text { Area } \\
(\text { ha) }\end{array}$ & $\begin{array}{r}\text { Average } \\
\text { slope }\left(^{\circ}\right)\end{array}$ & $\begin{array}{r}\text { Altitude } \\
(\mathrm{m} \text { a.s.l.) }\end{array}$ \\
\hline Mixed & & $\begin{array}{r}\text { Total 15.6) } \\
\text { Coniferous }\end{array}$ & 27.9 & $368-682$ \\
Leciduous & Walnut, maple, oak, lime, elm & 9.1 & & \\
Deciduous & Walnut, maple, oak, ash & 39 & 24.0 & $586-1005$ \\
\hline
\end{tabular}
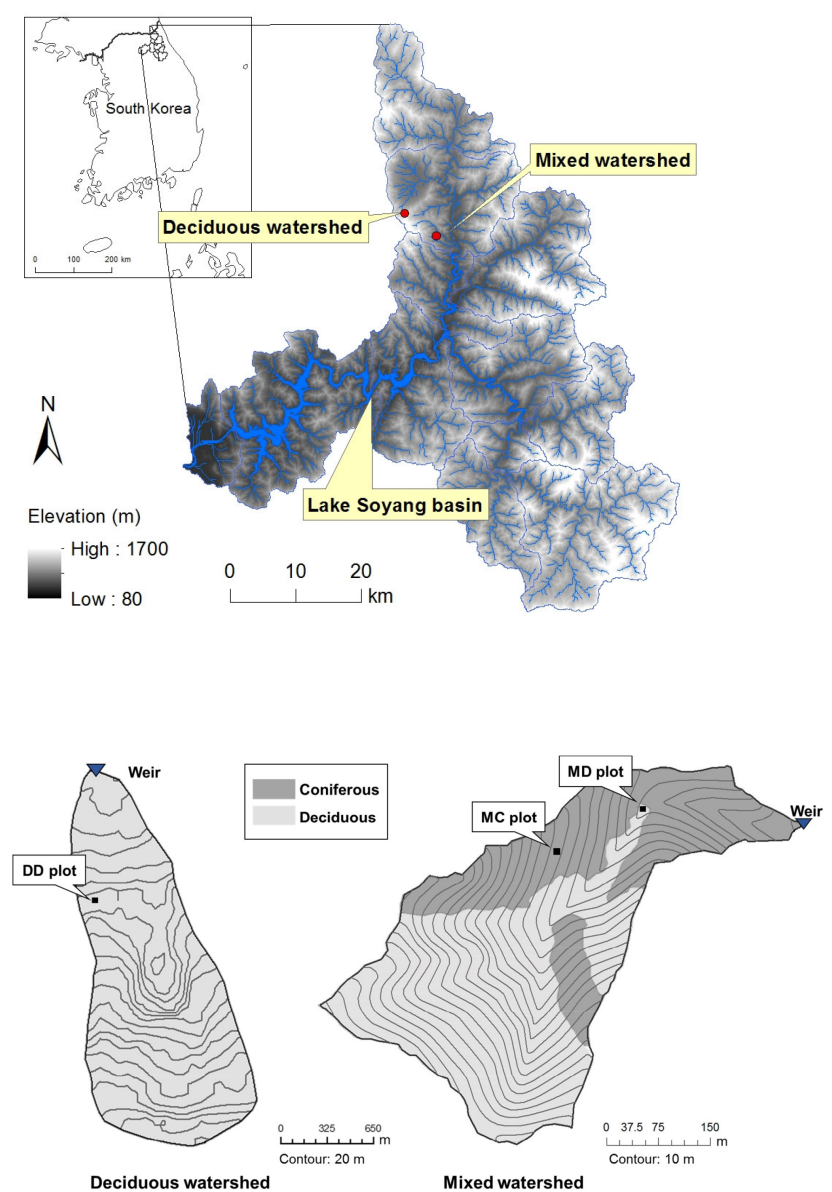

Figure 1. Location and tree species composition of the two studied forested watersheds. Lake Soyang map was modified from Jung et al. (2015).

The deciduous forested watershed (deciduous watershed; Fig. 1) is located in Haean, the Gangwon province $\left(38^{\circ} 15^{\prime} \mathrm{N}\right.$, $128^{\circ} 7^{\prime} \mathrm{E}$; 586 to $1005 \mathrm{~m}$ above sea level). The area of the deciduous watershed (Table 1) is 39 ha and is covered by various deciduous species. A research plot as deciduous plot (DD plot) was established in this watershed. The slope of the deciduous watershed ranges from 4 to $53^{\circ}$ with an average of $24^{\circ}$. The dominant tree species are Juglans mandshurica Maxim. (Manchurian walnut), Acer pictum subsp. mono (Maxim.) Ohashi (Mono maple), Quercus dentata
(Daimyo oak), Quercus mongolica (Mongolian oak), and Fraxinus rhynchophylla (Korean/Chinese ash). The average age of trees in the two watersheds is about 35 years. The distance between the two watersheds is ca. $6 \mathrm{~km}$.

\subsection{Experimental design}

\subsubsection{Water sampling}

Bulk precipitation samplers $(n=2)$ were installed at each watershed in an open area located $\sim 100 \mathrm{~m}$ from the plots. Throughfall collectors $(n=5)$ under the canopy were equipped with filters to prevent large particles from entering. Forest floor leachate was collected beneath the organic layer along the slope side using zero tension lysimeters $(n=5)$ of $185 \mathrm{~cm}^{2}$ made of acrylic material. Soil solution was collected at a depth of $\sim 50 \mathrm{~cm}$ with suction lysimeters $(n=5)$ made of ceramic cups.

Before storm events in June 2013, throughfall, forest floor leachate, and soil solution were collected at about weekly intervals, and runoff samples were collected two to three times per week. During storm events in July 2013, throughfall, forest floor leachate, and soil solution were collected after each storm event so that these samples represent cumulative water samples during the entire storm event. In case of runoff, samples were taken in July 2013 at the weir using automatic collectors (6712 Portable Sampler, Teledyne Isco Inc., Lincoln, NE, USA) before, during, and after each rain event at intervals of 1 or $2 \mathrm{~h}$. Discharge at the outlet of the watersheds was measured by a v-notch weir. During routine runoff sampling, water temperature, $\mathrm{pH}$, and electrical conductivity were measured in situ. Water samples were cooled at $4{ }^{\circ} \mathrm{C}$ and then were filtered (see Sect. 2.4) within 2 days after sampling. Filtered solution samples were frozen for 1 month until further analysis of water quality and quantity.

Precipitation data (total and hour unit; Table 2) at the study area were used from the automatic weather station of the Korean meteorological administration at the point "Seohwa 594" and "Haean 518" for the mixed watershed and for the deciduous watershed, respectively. Those data were also comparable to ours from bulk precipitation measurements at the field sites. 


\subsubsection{Soil sampling}

The total stock of organic horizons (Oi: slightly decomposed recognizable litter; Oe: moderately decomposed fragmented litter; Oa: highly decomposed humic material) was collected at each plot in a $20 \times 20 \mathrm{~cm}$ frame with 10 replicates. The average thickness of $\mathrm{Oi}$ and $\mathrm{Oe}+\mathrm{Oa}$ was 1.2 and $1.5 \mathrm{~cm}$ at the MC plot, 2.5 and $3 \mathrm{~cm}$ at the MD plot, and 2.3 and $2 \mathrm{~cm}$ at the DD plot, respectively. Mineral soil samples were collected from three pits at each plot in $10 \mathrm{~cm}$ depth layers down to $50 \mathrm{~cm}$ depth. In case of the DD plot, the sampling of mineral soil was not possible deeper than $40 \mathrm{~cm}$ depth due to massive rock. Before the analyses, soil samples were air-dried and crushed to pass through a $2 \mathrm{~mm}$ sieve. Soil $\mathrm{pH}$ was measured from a solution of a soil to solution $\left(0.01 \mathrm{MCaCl}_{2}\right)$ ratio of $1: 2.5$ after shaking for $2 \mathrm{~h}$. Total $\mathrm{C}$ and $\mathrm{N}$ contents were analyzed using an elemental analyzer (vario MAX CN, Elemental, Germany). Soil texture was determined by sedimentation.

\subsection{Calculation}

\subsubsection{Fluxes of $\mathrm{C}$ and $\mathrm{N}$ in runoff}

In June 2013, before the monsoon storm events, the fluxes of DOC were calculated on a weekly basis by multiplying the DOC weekly mean concentration in runoff by the weekly mean discharge. The concentrations of $\mathrm{DON}, \mathrm{NO}_{3}-$ $\mathrm{N}$, POC, and PON in runoff were partly below the detection limit. Concentrations less than detection limit were observed in $5-8 \%$ of the measurements in runoff during the July events. The detection limits were applied to the calculation of export fluxes as $0.03 \mathrm{mg} \mathrm{DON} \mathrm{L}^{-1}, 0.5 \mathrm{mg} \mathrm{NO}_{3}-$ $\mathrm{NL}^{-1}, 0.003 \mathrm{mg} \mathrm{POC} \mathrm{L}^{-1}$, and $0.0003 \mathrm{mg} \mathrm{PON} \mathrm{L}^{-1}$. During the period of storm events in July 2013, the fluxes of DOC, DON, $\mathrm{NO}_{3}-\mathrm{N}, \mathrm{POC}$, and PON in runoff were computed at 1 or $2 \mathrm{~h}$ intervals by multiplying the measured concentrations with the corresponding discharge. During the monsoon season the rainfall was not continuous on all days but rather had intermittent gaps. The most lasting rainfall events were identified as storm events with more than a day interval between each storm event.

\subsubsection{Statistics}

The normality of data was tested with the Shapiro-Wilk test. When the normality was assured, the Holm-Šidák test was used for both pairwise comparisons and comparisons to a control group. When the normality test failed, the Dunn's test was used for all pairwise comparisons and comparisons against a control group with rank-based ANOVA.

\subsection{Chemical analyses}

After filtration through a pre-rinsed cellulose acetate membrane filter $(0.45 \mu \mathrm{m}$, Whatman $)$, the concentrations of DOC and total dissolved nitrogen (TDN) in water samples were measured by a total organic carbon analyzer (TOC-CPH, Shimadzu, Japan). DON concentration was calculated as the difference between total nitrogen and mineral $\mathrm{N}\left(\mathrm{NO}_{3}^{-}+\mathrm{NH}_{4}^{+}\right)$. Nitrate and ammonium concentrations were measured by flow injection (FIA-LAB; MLE, Dresden, Germany). Nitrite was not measured because concentrations were negligible in soil solutions and runoff.

In this study, the POC and PON fraction is defined as the size class $0.7 \mu \mathrm{m}$ to $1 \mathrm{~mm}$. Samples were filtered through a $1 \mathrm{~mm}$ mesh to remove larger particulate materials and then finally filtered through a pre-rinsed $0.7 \mu \mathrm{m}$ pore size glass filter (GF/F, Whatman). Before using the glass filters, the filters were pre-combusted at $450^{\circ} \mathrm{C}$ to remove any organic material. The residues of particulate material on the GF/F filters were analyzed for POC and PON after drying at $65^{\circ} \mathrm{C}$ using an elemental analyzer (Carlo Erba1108, Milano, Italy) coupled to a ConFlo III interface and an isotope ratio mass spectrometer (Finnigan MAT, Bremen, Germany). DOC and POC cutoff limits as 0.45 and $0.7 \mu \mathrm{m}$ were unmatched in this study because of practical reasons and the unmatched fraction is considered negligible.

The absorption spectra of DOM were obtained at wavelengths from 200 to $600 \mathrm{~nm}$ using a UV-visible spectrophotometer (DR5000, HACH). Specific ultraviolet absorbance $\left(\mathrm{SUVA}_{280}\right)$ values were determined by UV absorbance at $280 \mathrm{~nm}$ divided by the DOC concentrations and multiplied by 100 .

For fluorescence excitation-emission matrices, fluorescence intensities were recorded with a luminescence spectrometer (LS-55, Perkin-Elmer, USA) following the method of Baker (2001), Chen et al. (2007), and Hur and Cho (2012). Excitation and emission slits were both adjusted to $10 \mathrm{~nm}$. DOM samples were diluted under the ultraviolet absorbance of 0.1 at $280 \mathrm{~nm}$ to avoid inner-filter correction and then were adjusted to $\mathrm{pH} 3.0$ for the fluorescence measurements. The fluorescence intensities of all samples were normalized to units of quinine sulfate equivalents. The humification index (HIXem) was calculated by dividing the emission intensity from 435 to $480 \mathrm{~nm}$ region by intensity from 300 to $345 \mathrm{~nm}$ (Zsolnay et al., 1999). Fluorescence characteristics of water samples were interpreted as fulvic-like fluorescence (FLF), humic-like fluorescence (HLF), and protein-like fluorescence (PLF) (Fellman et al., 2010; Singh et al., 2014).

After filtration $(0.45 \mu \mathrm{m}$, Whatman), water samples were freeze-dried to measure ${ }^{13} \mathrm{C}$ and ${ }^{15} \mathrm{~N}$ isotope abundances of DOC and TDN using an elemental analyzer (Carlo Erba1108, Milano, Italy) coupled to a ConFlo III interface and an isotope ratio mass spectrometer (Finnigan MAT, Bremen, Germany). 


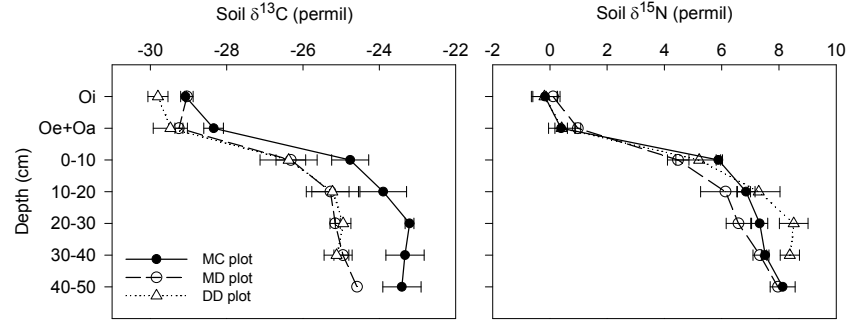

Figure 2. Soil profiles of ${ }^{13} \mathrm{C}$ and ${ }^{15} \mathrm{~N}$ isotope abundance at the $\mathrm{MC}$, $\mathrm{MD}$, and DD plot. Error bars represent standard deviation $(n=3)$.

\section{Results}

\subsection{Soil and hydrological characteristics}

The morphologies of the organic layers at the MC, MD, and DD plots were similar with distinct Oi layers and less distinct $\mathrm{Oe}$ and $\mathrm{Oa}$ layers. However, the depth of O layer in the MC plot (ca. $3 \mathrm{~cm}$ ) was thinner than in the MD and DD plot (ca. $4-5 \mathrm{~cm}$ ). The typical soil type at both watersheds is Dystric Cambisol (FAO, 2014). Soil texture at all plots ranged from 40-44, 30-38, and 18-22\% for sand, silt, and clay, respectively. The $\mathrm{C}$ content of the organic layers at all plots ranged from 45 to $48 \%$ in the Oi and from 34 to $38 \%$ in the $\mathrm{Oe}+\mathrm{Oa}$ layers. The $\mathrm{C} / \mathrm{N}$ ratio at all plots decreased from the organic layer (20-29) to the mineral soil (10-12) down to $40-50 \mathrm{~cm}$ depth. The soil $\delta^{13} \mathrm{C}$ and soil $\delta^{15} \mathrm{~N}$ values significantly increased with soil depth from -29 to $-24 \%$ and from 0 to $8 \%$, respectively (Fig. 2).

The average discharge in June 2013 before storm events was $0.03 \mathrm{~mm} \mathrm{~h}^{-1}$ at the mixed watershed and $0.06 \mathrm{~mm} \mathrm{~h}^{-1}$ at the deciduous watershed (data not shown). The total amount of precipitation in July was slightly higher at the deciduous watershed $(367 \mathrm{~mm})$ than at the mixed watershed $(313 \mathrm{~mm}$; Table 2). Also, the intensity of precipitation in July was larger at the deciduous watershed than at the mixed watershed. Similar to precipitation data, the mixed watershed had less maximum discharge and also slightly lower discharge before start of a storm event than the deciduous watershed.

\subsection{Concentrations of carbon and nitrogen in runoff during storm events}

The increase of the DOC concentrations in runoff with discharge was steeper at the deciduous watershed (e.g., 1.9 to $6.9 \mathrm{mg} \mathrm{CL}^{-1}$ on 8 July 2013) than at the mixed watershed (e.g., 1.0 to $3.7 \mathrm{mg} \mathrm{C} \mathrm{L}^{-1}$ on 8 July 2013) (Fig. 3a). In contrast, the DON concentrations in runoff from both watersheds were independent of discharge (Fig. 3b). The highest concentration of DOC and DON in runoff was observed during the earlier storm events (Table 2). The $\mathrm{NH}_{4}-\mathrm{N}$ concentrations were at any time negligible $\left(<0.05 \mathrm{mg} \mathrm{N} \mathrm{L}^{-1}\right)$.

At discharges from $\sim 1$ to $9 \mathrm{~mm} \mathrm{~h}^{-1}$, higher concentrations of POC and PON in runoff were found (Fig. 3d, e). For

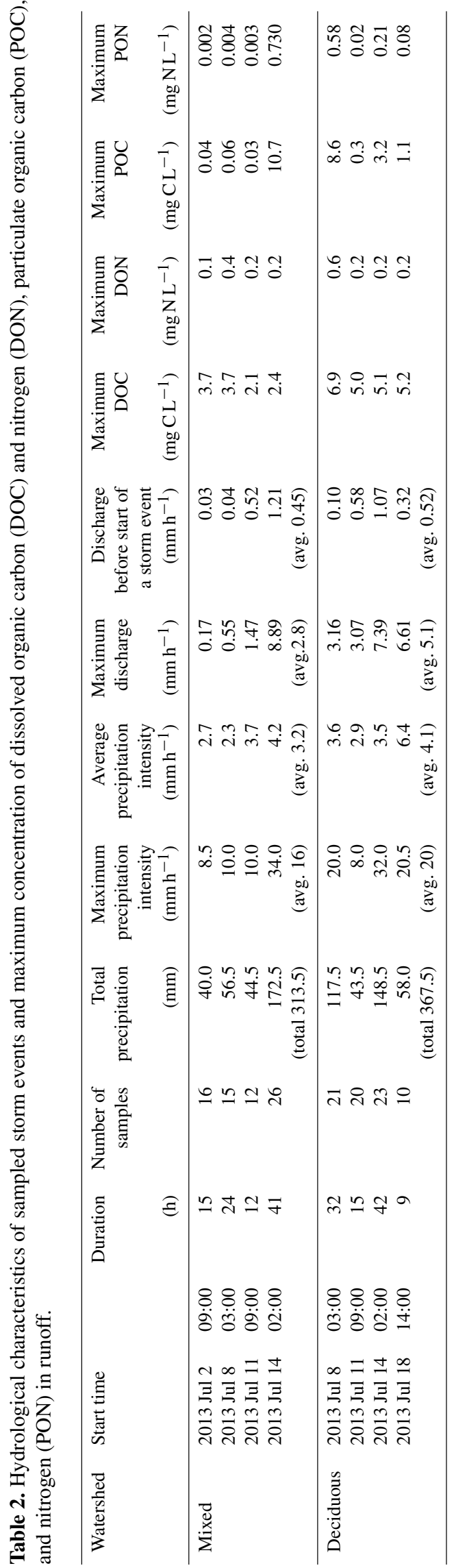



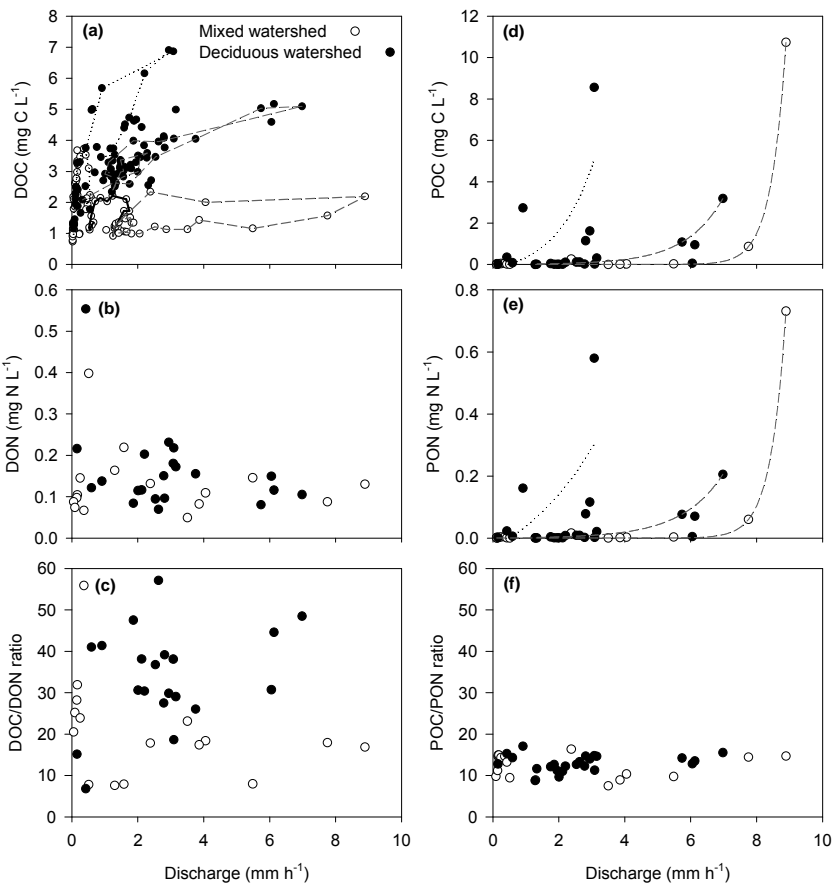

Figure 3. Concentrations of (a) dissolved organic carbon (DOC) and (b) nitrogen (DON), (d) particulate organic carbon (POC), and (e) nitrogen (PON) and the ratios of (c) DOC/DON and (f) POC / PON in runoff with discharge during monsoon storm events. Doted, solid, and dashed lines correspond to the storm event of 8,11 , and 14 July 2013 , respectively.

example, the POC concentration in runoff from the mixed watershed was as high as $10.7 \mathrm{mg} \mathrm{C} \mathrm{L}^{-1}$ at the largest discharge of $9 \mathrm{~mm} \mathrm{~h}^{-1}$. At the deciduous watershed, the POC concentration in runoff reached a maximum of $8.6 \mathrm{mg} \mathrm{CL}^{-1}$ already at $3 \mathrm{~mm} \mathrm{~h}^{-1}$ discharge during the first storm event (Fig. 3d, Table 2). The following more intense storms did result in lower POC concentrations. The pattern of POC concentration coincided with those of PON $(r=0.99)$.

The runoff DOC concentrations in response to discharge had a clockwise hysteretic loop with higher concentrations on the rising than on the falling limb (Fig. 3a). No hysteretic loops were observed for DON, POC, and PON (Fig. 3b, d, e).

The DOC/DON ratio in runoff ranged from 5 to 60 (Fig. 3c). The DON concentrations lower than $0.05 \mathrm{mg} \mathrm{N} \mathrm{L}^{-1}$ were not considered for calculation of the DOC / DON ratios. In response to increased discharge, the DOC / DON ratios were stable at the mixed watershed, while there was a tendency for increasing in the DOC / DON ratios with discharge at the deciduous watershed. In contrast, there was no response of the POC / PON ratio to discharge. Unlike to the DOC / DON ratio, the POC / PON ratio ranged narrowly from 10 to 20 at both watersheds (Fig. 3f) with an average of 12 at the mixed and 13 at the deciduous watershed.
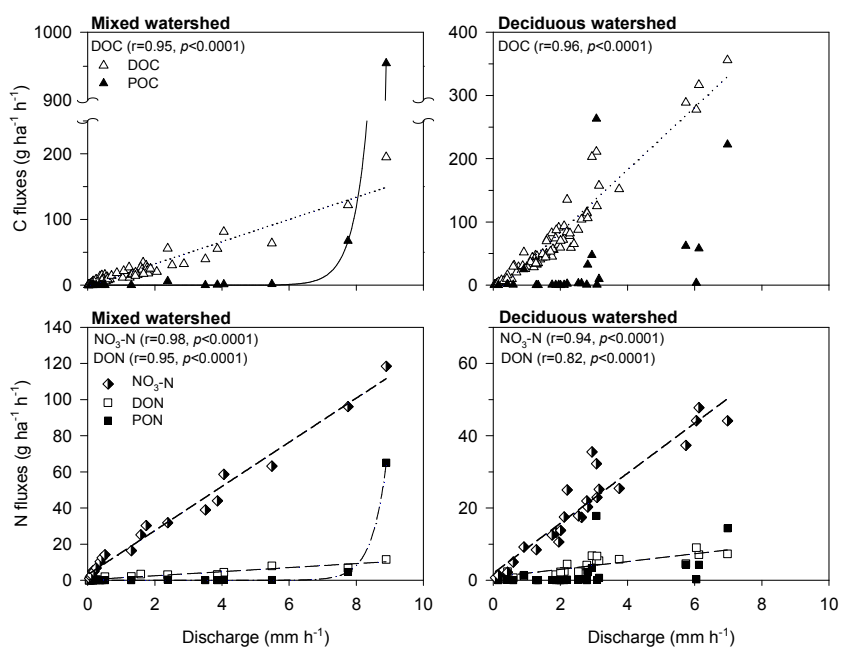

Figure 4. Fluxes of carbon (dissolved organic carbon (DOC) and particulate organic carbon (POC)) and nitrogen (dissolved organic nitrogen (DON), particulate organic nitrogen (PON), and nitrate $\left.\left(\mathrm{NO}_{3}-\mathrm{N}\right)\right)$ in runoff with discharge during monsoon storm events.

\subsection{Fluxes of carbon and nitrogen}

The fluxes of DOC, DON, and $\mathrm{NO}_{3}-\mathrm{N}$ in runoff were linearly correlated to discharge at both watersheds (Fig. 4). The DOC fluxes at the deciduous watershed increased with a much steeper slope in response to discharge than at the mixed watershed, while the $\mathrm{NO}_{3}-\mathrm{N}$ fluxes at the mixed watershed more steeply increased with increasing discharge than at the deciduous. The POC fluxes were generally much lower than the DOC fluxes, but the POC and PON fluxes increased in a nonlinear response to discharge. Only at a single peak flow event on 14 July 2013, the POC fluxes at the mixed watershed were 5 times greater than the DOC fluxes. The same trend was found for the PON and DON fluxes. At the deciduous watershed, only one event caused slightly larger POC than DOC fluxes.

The integrated $\mathrm{C}$ and $\mathrm{N}$ fluxes over the study period from both watersheds were in the order of DOC $>\mathrm{POC}$ and $\mathrm{NO}_{3}-$ $\mathrm{N}>$ DON $>$ PON (Table 3). The DOC fluxes as the dominant $\mathrm{C}$ flux form contributed 75 and $92 \%$ of the total organic C flux at the mixed and the deciduous watersheds, respectively. The integrated fluxes of DOC and DON were higher at the deciduous watershed $\left(16 \mathrm{~kg} \mathrm{Cha}^{-1}\right.$ and $\left.0.5 \mathrm{~kg} \mathrm{~N} \mathrm{ha}^{-1}\right)$ than at the mixed watershed $\left(6.7 \mathrm{~kg} \mathrm{Cha}^{-1}\right.$ and $\left.0.26 \mathrm{~kg} \mathrm{Nha}^{-1}\right)$. The integrated fluxes of POC and PON were small at both watersheds with only minor differences. Before storm events in June 2013, POC and PON were almost not exported at both watersheds. However, the integrated fluxes of POC and PON increased extremely during heavy storm events in July 2013. The $\mathrm{NO}_{3}-\mathrm{N}$ fluxes as the dominant $\mathrm{N}$ flux form represented 93 and $82 \%$ of the total $\mathrm{N}$ flux in runoff at the mixed and the deciduous watershed, respectively. The integrated fluxes of $\mathrm{NO}_{3}-\mathrm{N}$ were about twice as high $\left(5.2 \mathrm{~kg} \mathrm{Nha}^{-1}\right)$ 

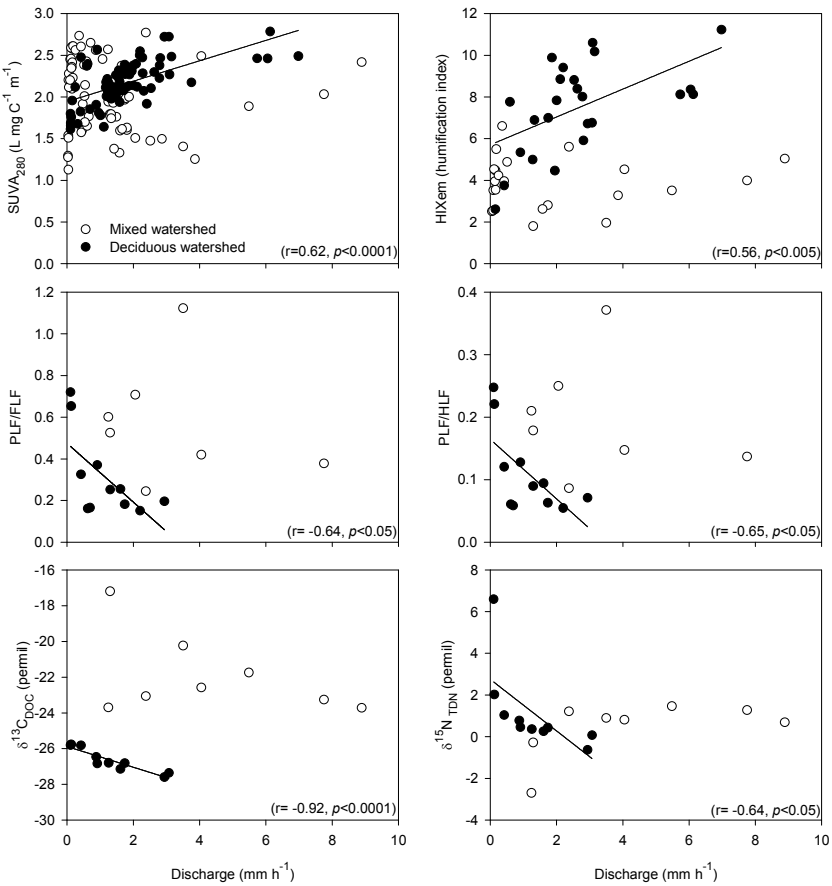

Figure 5. Specific ultraviolet absorbance $\left(\mathrm{SUVA}_{280}\right)$, humification index (HIXem), protein-like fluorescence/humic-like fluorescence (PLF/HLF), protein-like fluorescence/fulvic-like fluorescence (PLF/FLF), ${ }^{13} \mathrm{C}$ isotope abundance of dissolved organic carbon $\left(\delta^{13} \mathrm{C}_{\mathrm{DOC}}\right)$, and ${ }^{15} \mathrm{~N}$ isotope abundance of total dissolved nitrogen $\left(\delta^{15} \mathrm{~N}_{\mathrm{TDN}}\right)$ in runoff with discharge during monsoon storm events. Only significant regressions are shown.

at the mixed watershed than at the deciduous watershed $\left(2.9 \mathrm{~kg} \mathrm{Nha}^{-1}\right)$.

\subsection{Chemical properties of DOM and POM in runoff}

The chemical properties of DOM changed with increased discharge at the deciduous watershed, while no significant changes were observed at the mixed watershed (Fig. 5). At the deciduous watershed, $\mathrm{SUVA}_{280}$ and HIXem increased with increased discharge, while PLF/FLF, PLF/HLF, $\delta^{13} \mathrm{C}_{\text {DOC }}$, and $\delta^{15} \mathrm{~N}_{\mathrm{TDN}}$ decreased.

At the mixed watershed, the ranges of the DOC / DON ratio, $\mathrm{SUVA}_{280}$, and HIXem in runoff were similar to those in throughfall and soil solution, while PLF/FLF and PLF/HLF in runoff corresponded more to those in forest floor percolates (Fig. 6). In contrast, at the deciduous watershed, these parameters in runoff were closely related to the quality of forest floor leachates. Also, the ${ }^{13} \mathrm{C}$ data in runoff, being more negative at the deciduous watershed, point to a larger proportion of forest floor leachates in runoff than at the coniferous watershed.

The patterns of DOC / DON ratios in response to discharge were also different at the two watersheds (Fig. 3c). Large DOC / DON ratios at high discharge at the deciduous
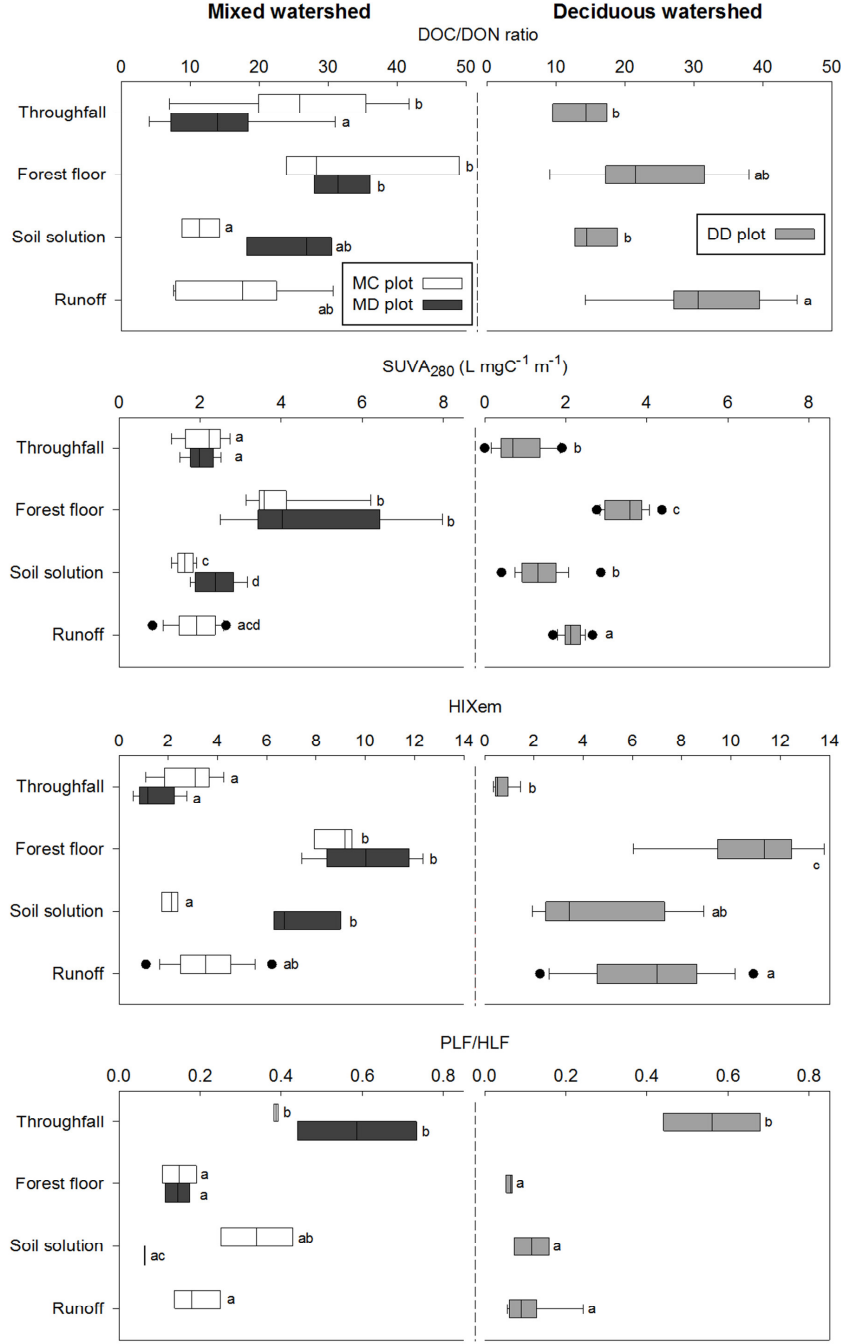

Figure 6. Range of dissolved organic carbon and nitrogen ratio (DOC / DON ratio), specific ultraviolet absorbance (SUVA 280 ), humification index (HIXem), and protein-like fluorescence/humic-like fluorescence (PLF/HLF) of throughfall, forest floor leachates, soil solution, and runoff during monsoon storm events. Box plots display minimum, lower quartile, median, upper quartile, maximum, and outliers. Statistically significant differences between sample types (throughfall, forest floor leachates, soil solution, and runoff) are indicated by different letters in the box plots (significance level of $p<0.05)$.

watershed resulted from the positive response of DOC concentration and the stable DON concentration to discharge. The DOC / DON ratios at the coniferous watershed were stable in response to discharge.

The range of the POC / PON ratio in runoff was similar to that of the POC/PON ratio of mineral soil layers at both watersheds (Fig. 7). The same holds for the $\delta^{13} \mathrm{C}_{\mathrm{POC}}$ values. The $\delta^{15} \mathrm{~N}_{\mathrm{PON}}$ in runoff had a huge variation, with averages being larger than those of the forest floor, but less than those of the mineral soil. 
Table 3. Total precipitation, total runoff, and integrated fluxes of dissolved organic carbon (DOC) and nitrogen $(\mathrm{DON})$, nitrate $\left(\mathrm{NO}_{3}-\mathrm{N}\right)$, particulate organic carbon (POC), and nitrogen (PON) in June and July 2013.

\begin{tabular}{llrrrrrrr}
\hline Watershed & Period & $\begin{array}{r}\text { Total precipitation } \\
(\mathrm{mm})\end{array}$ & $\begin{array}{r}\text { Total runoff } \\
(\mathrm{mm})\end{array}$ & $\begin{array}{r}\text { DOC fluxes } \\
\left(\mathrm{kg} \mathrm{Cha}^{-1}\right)\end{array}$ & $\begin{array}{r}\text { DON fluxes } \\
\left(\mathrm{kg} \mathrm{h} \mathrm{ha}^{-1}\right)\end{array}$ & $\begin{array}{r}\mathrm{NO}_{3}-\mathrm{N} \mathrm{fluxes} \\
\left(\mathrm{kg} \mathrm{h} \mathrm{ha}^{-1}\right)\end{array}$ & $\begin{array}{r}\text { POC fluxes } \\
\left(\mathrm{kg} \mathrm{Cha}^{-1}\right)\end{array}$ & $\begin{array}{r}\text { PON fluxes } \\
\left(\mathrm{kg} \mathrm{ha}^{-1}\right)\end{array}$ \\
\hline \multirow{2}{*}{ Mixed } & June $^{\mathrm{a}}$ & 86.0 & 21.8 & 0.22 & 0.02 & 0.43 & 0.001 & 0.0001 \\
& July $^{\mathrm{b}}$ & 508.0 & 380.7 & 6.74 & 0.26 & 5.20 & 2.22 & 0.15 \\
Deciduous & June $^{\mathrm{a}}$ & 70.5 & 52.4 & 0.85 & 0.1 & 0.52 & 0.01 & 0.001 \\
& July $^{\mathrm{b}}$ & 498.0 & 439.5 & 16.13 & 0.52 & 2.87 & 1.46 & 0.11 \\
\hline
\end{tabular}

${ }^{\mathrm{a}}$ Before heavy storm events from 1 to 30 June 2013. ${ }^{\mathrm{b}}$ Heavy storm events from 1 to 20 July 2013.
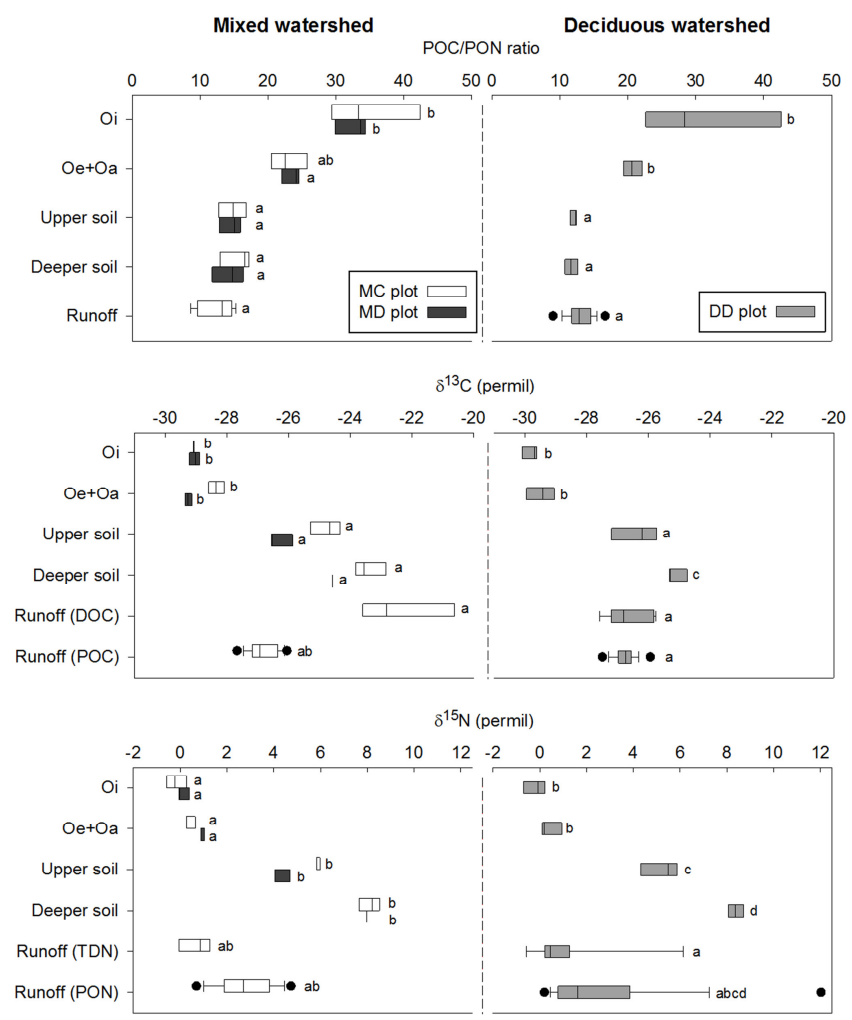

Figure 7. Range of particulate organic carbon and nitrogen ratio (POC / PON ratio), $\delta^{13} \mathrm{C}$ and $\delta^{15} \mathrm{~N}$ in Oi, Oe+Oa, upper soil (0$10 \mathrm{~cm}$ depth), deeper soil (40-50 cm depth at the MC and MD plot, $30-40 \mathrm{~cm}$ depth at the DD plot), and runoff. Box plots display minimum, lower quartile, median, upper quartile, maximum, and outliers. Statistically significant differences between sample types (Oi, $\mathrm{Oe}+\mathrm{Oa}$, upper soil, deeper soil, and runoff) are indicated by different letters in the box plots (significance level of $p<0.05$ ).

\section{Discussion}

\subsection{Different response of DOC to increased discharge at the mixed and the deciduous watershed}

We intensively sampled four heavy rainfall events during the monsoon season, the events representing a substantial proportion of the annual precipitation in the region. While

the number of events was rather small, consistent patters emerged documenting the response of $\mathrm{N}$ and $\mathrm{C}$ fluxes to precipitation and discharge changes. The increase of DOC concentrations and fluxes in runoff induced by heavy storm events with increased discharge is consistent with the findings of previous studies (Dhillon and Inamdar, 2013; Jeong et al., 2012; Johnson et al., 2006; Lloret et al., 2013). In our study, the response to discharge and the integrated fluxes of DOC in runoff were much larger at the deciduous than at the mixed watershed. Similar to our results, larger annual DOC fluxes at a deciduous forested catchment than at a mixed coniferous catchment were reported by Amiotte-Suchet et al. (2007).

The different response of DOM in runoff to discharge between the two watersheds, such as the large response of runoff DOC concentration to discharge at the deciduous watershed (Fig. 3a) and the significant change in runoff DOC quality parameters (Fig. 5), is likely caused by a shift of hydrological flow paths to more surficial layers at the deciduous watershed. Also, the comparison of DOC quality parameters in runoff with those in forest floor leachates and soil solution at the deciduous watershed (Fig. 6) indicated that a larger proportion of the DOC in runoff from forest floor leachates at the deciduous. Previous studies have also reported a positive relationships between discharge and DOM concentrations in runoff as a consequence of changing hydrologic flow paths from deeper soil to upper soil layers and forest floors at high discharge (Aitkenhead-Peterson et al., 2005; Bass et al., 2011; Sanderman et al., 2009). As several watershed characteristics (slope and soil textures) and the precipitation regime at both watersheds were similar, the differences between the watersheds are likely due to the tree species effects on the infiltration of precipitation water into the soil and on the mobilization of DOM. The tree species effect became obvious although the proportion of coniferous tree species was only $39 \%$ of the watershed area. Several processes might be involved to explain the tree species effect. (i) In the deciduous litter layer the leaves are overlapping and partly impermeable, which may cause more surface near flow than in coniferous litter layers with relatively large pore spaces in between needles. (ii) The relatively higher level of hydrophobicity of coniferous forest floors compared to deciduous forest floors 
(Butzen et al., 2014) can result in less DOC release from coniferous forest floors. (iii) The mobilization of DOC in soils depends on throughfall chemistry (Kalbitz et al., 2000). Throughfall at the MC plot was more acidic ( $\mathrm{pH} 4.7 \pm 0.4)$ and had a higher ionic strength $\left(15.9 \pm 11.3 \mu \mathrm{S} \mathrm{cm}^{-1}\right)$ than at the DD plot (pH $\left.6.1 \pm 0.2,10.3 \pm 6.3 \mu \mathrm{S} \mathrm{cm}^{-1}\right)$ and the MD plot ( $\left.\mathrm{pH} 5.8 \pm 0.4,9.0 \pm 6.3 \mu \mathrm{S} \mathrm{cm}^{-1}\right)$. Acidity and ionic strength are negatively related to DOC release from soils (Clark et al., 2011; Michalzik et al., 2001; Moldan et al., 2012). (iv) In-stream generation of DOC from litter might be involved (Johnson et al., 2006) if more leaf than needle litter enters the stream. (v) As the deciduous watershed is located at a higher altitude the soils might generally be shallower than at the mixed watershed, which will add to the larger near-surface flow paths under high precipitation. (vi) Faster decomposition of the deciduous litter leaches relatively more DOM, resulting in higher DOC export fluxes at the deciduous than at the mixed watershed. Based on our data set of this study, one cannot quantify the relative importance of these factors causing the differences between the watersheds.

\subsection{Organic and inorganic nitrogen in runoff}

At both watersheds, $\mathrm{NO}_{3}-\mathrm{N}$ was the dominant form of total $\mathrm{N}$ flux in runoff (Table 3). Several studies have reported that DON accounted for the dominant fraction of $\mathrm{N}$ flux in undisturbed forested watersheds (Alvarez-Cobelas et al., 2008; Frank et al., 2000; Kaushal and Lewis, 2003; Pellerin et al., 2006). Substantial fluxes of $\mathrm{NO}_{3}-\mathrm{N}$ and the dominance of $\mathrm{NO}_{3}-\mathrm{N}$ over DON in runoff are likely due to a certain degree of $\mathrm{N}$ saturation ( $\mathrm{N}$ supply $>\mathrm{N}$ demand) of these forested watersheds (Aber et al., 1998; Compton et al., 2003). Hence, the finding of the dominant $\mathrm{NO}_{3}-\mathrm{N}$ of total $\mathrm{N}$ flux implies that the $\mathrm{N}$ deposition in the area is quite high (estimated between 24 and $51 \mathrm{~kg} \mathrm{Nha}^{-1} \mathrm{yr}^{-1}$;) Berger et al., 2013). In July 2013, the integrated $\mathrm{N}$ flux in throughfall was, however, similar at the both watersheds (data not shown). Hence, the differences in $\mathrm{N}$ deposition between the two watersheds unlikely explain higher $\mathrm{NO}_{3}-\mathrm{N}$ fluxes in runoff at the mixed than at the deciduous watershed (Table 3). The $\mathrm{C} / \mathrm{N}$ ratio of the forest floor was found to be a good indicator of $\mathrm{NO}_{3}-\mathrm{N}$ release with increasing fluxes at low $\mathrm{C} / \mathrm{N}$ ratios (Borken and Matzner, 2004; MacDonald et al., 2002). However, the C / N ratio of the organic layer at the mixed watershed (20-28) was higher than at the deciduous watershed (19-21), which does not agree with the findings of MacDonald et al. (2002). Overall, it seems that a larger $\mathrm{N}$ uptake by the deciduous trees at the deciduous watershed could explain the differences in the $\mathrm{NO}_{3}-\mathrm{N}$ fluxes.

\subsection{Particulate organic matter in runoff}

The integrated fluxes of POC and PON during the study period were much less than those of the dissolved elements and did not differ significantly between the watersheds. POC and PON fluxes exceeded their dissolved fractions only for a short time during heavy storm events with more than $100 \mathrm{~mm}$ precipitation except one storm event at the deciduous watershed on 14 July 2013 (Table 2). Previous studies in the nearby region considered $100 \mathrm{~mm}$ precipitation as the threshold that would induce large POC fluxes (Jeong et al., 2012; Jung et al., 2012). Our finding indicates that POM fluxes from forested watershed are unlikely regulated solely by precipitation amount, but slope and river bench characteristics will interfere. The small proportion of particulate fluxes in our study seems to be mainly caused by the relatively moderate precipitation events during the study period. The POC / PON ratios in runoff as well as the $\delta^{13} \mathrm{C}_{\mathrm{POC}}$ and $\delta^{15} \mathrm{~N}_{\mathrm{PON}}$ were similar to those of the mineral soil and different to those of the forest floor. This indicates that the particulate matter originated from the erosion of mineral soil along the stream benches. Higher annual POC fluxes than DOC fluxes were observed in some mountainous forested watersheds (Kao and Liu, 1997; Kim et al., 2010; Lloret et al., 2013), which does not agree with our finding and some other studies (Dhillon and Inamdar, 2013; Inamdar et al., 2011; Jeong et al., 2012). The differences in findings may be related to the topography of forested watershed because steeper slopes induce higher fluxes of POC (Hilton et al., 2012; Janeau et al., 2014; Jung et al., 2012).

\section{Conclusions}

Our study emphasized the role of heavy precipitation events and vegetation cover for the export fluxes of particulate and dissolved organic $\mathrm{C}$ and $\mathrm{N}$ with runoff from forested watersheds. Our results suggest that changes of the precipitation regime, with more severe monsoon storms in the future as predicted, will increase the export of dissolved and particulate organic matter from these watersheds. The proportion of coniferous tree species at the mixed watershed was sufficient to induce less DOC fluxes and larger $\mathrm{NO}_{3}-\mathrm{N}$ fluxes with runoff as compared to the deciduous watershed. Differences in the flow paths between the watersheds are seen as the major trigger for the differences in runoff with a larger proportion of near-surface flow at the deciduous watershed. A larger proportion of coniferous forests will likely lead to less input of organic carbon and more input of inorganic nitrogen to the receiving surface water bodies.

\section{Data availability}

Average annual and monthly temperatures of the western Gangwon province from 1981 to 2010 were obtained from the Korean Meteorological Administration (http://www.kma.go.kr/weather/climate/average_30years. jsp?yy_st=2011\&stn=0\&norm=M\&x=23\&y=2\&obs=TA). Hydrological characteristics of precipitation events (start time, duration, hourly precipitation amount, and hourly pre- 
cipitation intensity) during June and July 2013 were accessed from the Korean Meteorological Administration (http:// www.kma.go.kr/weather/observation/aws_table_popup.jsp). Data of the digital elevation model of two watersheds are available from the Korean National Geographic Information Institute (http://www.vworld.kr/po_intdata_a001.do). Supplements related to this article are available at https://epub.uni-bayreuth.de/id/eprint/2787. Original data are accessible as Excel files under doi:10.15495/M10150123-0001.

Author contributions. Mi-Hee Lee carried out the experimental work and data evaluation and prepared the manuscript with contribution from all co-authors. Egbert Matzner and Ji-Hyung Park contributed to the design of this study, to data evaluation, interpretation of results, and writing of the manuscript. Jean-Lionel Payeur-Poirier supported the field work and provided the discharge data.

Acknowledgements. This study was accomplished within the framework of the International Research Training Group TERRECO (GRK 1565/1) and funded by the German Research Foundation (Deutsche Forschungsgemeinschaft; DFG) at the University of Bayreuth and the Korean Research Foundation (KRF) at Kangwon National University. We acknowledge the BayCEER Laboratory of Isotope Biogeochemistry for the isotope abundance analysis and the Central Analytical Department of BayCEER for mineral-N measurements at the University of Bayreuth. We are grateful to other TERRECO colleagues for the comprehensive support and to Uwe Hell for the sampler installation of soil solution. We also appreciate the international collaboration with Bomchul Kim, Youngsoon Choi, and Jaesung Eum from Kangwon National University (Chuncheon) and with Jin Hur and Bomi Lee from Sejong University (Seoul). The publication was supported by the University of Bayreuth in the funding program Open Access Publishing.

Edited by: M. Sarin

Reviewed by: D. Kumar and one anonymous referee

\section{References}

Aber, J., McDowell, W., Nadelhoffer, K., Magill, A., Berntson, G., Kamakea, M., McNulty, S., Currie, W., Rustad, L., and Fernandez, I.: Nitrogen Saturation in Temperate Forest Ecosystems, Bioscience, 48, 921-934, doi:10.2307/1313296, 1998.

Aitkenhead-Peterson, J. A., Alexander, J. E., and Clair, T. A.: Dissolved organic carbon and dissolved organic nitrogen export from forested watersheds in Nova Scotia: Identifying controlling factors, Global Biogeochem. Cy., 19, 1-8, doi:10.1029/2004GB002438, 2005.

Alvarez-Cobelas, M., Angeler, D. G., and Sánchez-Carrillo, S.: Export of nitrogen from catchments: A worldwide analysis, Environ. Pollut., 156, 261-269, doi:10.1016/j.envpol.2008.02.016, 2008.
Amiotte-Suchet, P., Linglois, N., Leveque, J., and Andreux, F.: ${ }^{13} \mathrm{C}$ composition of dissolved organic carbon in upland forested catchments of the Morvan Mountains (France): Influence of coniferous and deciduous vegetation, J. Hydrol., 335, 354-363, doi:10.1016/j.jhydrol.2006.12.002, 2007.

Baker, A.: Fluorescence excitation - Emission matrix characterization of some sewage-impacted rivers, Environ. Sci. Technol., 35, 948-953, doi:10.1021/es000177t, 2001.

Bass, A. M., Bird, M. I., Liddell, M. J., and Nelson, P. N.: Fluvial dynamics of dissolved and particulate organic carbon during periodic discharge events in a steep tropical rainforest catchment, Limnol. Oceanogr., 56, 2282-2292, doi:10.4319/lo.2011.56.6.2282, 2011.

Bauer, J. E. and Bianchi, T. S.: Dissolved Organic Carbon Cycling and Transformation, in Treatise on Estuarine and Coastal Science, Elsevier, vol. 5, 7-67, 2011.

Berger, S., Jung, E., Köpp, J., Kang, H., and Gebauer, G.: Monsoon rains, drought periods and soil texture as drivers of soil $\mathrm{N}_{2} \mathrm{O}$ fluxes - Soil drought turns East Asian temperate deciduous forest soils into temporary and unexpectedly persistent $\mathrm{N}_{2} \mathrm{O}$ sinks, Soil Biol. Biochem., 57, 273-281, doi:10.1016/j.soilbio.2012.09.026, 2013.

Bianchi, T. S.: The role of terrestrially derived organic carbon in the coastal ocean: A changing paradigm and the priming effect, P. Natl. Acad. Sci. USA, 108, 19473-19481, doi:10.1073/pnas.1017982108, 2011.

Borken, W. and Matzner, E.: Nitrate leaching in forest soils: an analysis of long-term monitoring sites in Germany, J. Plant Nutr. Soil Sc., 167, 277-283, doi:10.1002/jpln.200421354, 2004.

Butzen, V., Seeger, M., Wirtz, S., Huemann, M., Mueller, C., Casper, M., and Ries, J. B.: Quantification of Hortonian overland flow generation and soil erosion in a Central European low mountain range using rainfall experiments, Catena, 113, 202212, doi:10.1016/j.catena.2013.07.008, 2014.

Camino-Serrano, M., Gielen, B., Luysaert, S., Ciais, P., Vicca, S., Guenet, B., de Vos, B., Cools, N., Ahrens, B., Arain, M. A., Borken, W., Clarke, N., Clarkson, B., Cummins, T., Don, A., Pannatier, E. G., Laudon, H., Moore, T., Nieminen, T. M., Nilsson, M. B., Peichl, M., Schwendenmann, L., Siemens, J., and Janssens, I.: Linking variability in soil solution dissolved organic carbon to climate, soil type, and vegetation type, Global Biogeochem. Cy., 28, 497-509, doi:10.1002/2013GB004726, 2014.

Canham, C. D., Pace, M. L., Weathers, K. C., McNeil, E. W., Bedford, B. L., Murphy, L., and Quinn, S.: Nitrogen deposition and lake nitrogen concentrations: a regional analysis of terrestrial controls and aquatic linkages, Ecosphere, 3, 1-16, doi:10.1890/ES12-00090.1, 2012.

Chen, Z., Hu, C., Conmy, R. N., Muller-Karger, F., and Swarzenski, P.: Colored dissolved organic matter in Tampa Bay, Florida, Mar. Chem., 104, 98-109, doi:10.1016/j.marchem.2006.12.007, 2007.

Clark, J. M., Van Der Heijden, G. M. F., Palmer, S. M., Chapman, P. J., and Bottrell, S. H.: Variation in the sensitivity of DOC release between different organic soils following $\mathrm{H}_{2} \mathrm{SO}_{4}$ and seasalt additions, Eur. J. Soil Sci., 62, 267-284, doi:10.1111/j.13652389.2010.01344.x, 2011.

Compton, J. E., Church, M. R., Larned, S. T., and Hogsett, W. E.: Nitrogen export from forested watersheds in the oregon coast range: The role of $\mathrm{N}_{2}$-fixing Red alder, Ecosystems, 6, 773-785, doi:10.1007/s10021-002-0207-4, 2003. 
Dhillon, G. S. and Inamdar, S.: Extreme storms and changes in particulate and dissolved organic carbon in runoff: Entering uncharted waters?, Geophys. Res. Lett., 40, 1322-1327, doi:10.1002/grl.50306, 2013.

Don, A. and Kalbitz, K.: Amounts and degradability of dissolved organic carbon from foliar litter at different decomposition stages, Soil Biol. Biochem., 37, 2171-2179, doi:10.1016/j.soilbio.2005.03.019, 2005.

Fellman, J. B., Hood, E., and Spencer, R. G. M.: Fluorescence spectroscopy opens new windows into dissolved organic matter dynamics in freshwater ecosystems: A review, Limnol. Oceanogr., 55, 2452-2462, doi:10.4319/lo.2010.55.6.2452, 2010.

Frank, H., Patrick, S., Peter, W., and Hannes, F.: Export of dissolved organic carbon and nitrogen from Gleysol dominated catchments - The significance of water flow paths, Biogeochemistry, 50, 137-161, doi:10.1023/A:1006398105953, 2000.

Food and Agriculture Organization of the United Nations (FAO): World reference base for soil resources 2014 international soil classification system for naming soils and creating legends for soil maps, Rome, 2014.

Hansson, K., Olsson, B. A., Olsson, M., Johansson, U., and Kleja, D. B.: Differences in soil properties in adjacent stands of Scots pine, Norway spruce and silver birch in SW Sweden, Forest Ecol. Manag., 262, 522-530, doi:10.1016/j.foreco.2011.04.021, 2011.

Hilton, R. G., Galy, A., Hovius, N., Kao, S.-J., Horng, M.-J., and Chen, H.: Climatic and geomorphic controls on the erosion of terrestrial biomass from subtropical mountain forest, Global Biogeochem. Cy., 26, GB3014, doi:10.1029/2012GB004314, 2012.

Hur, J. and Cho, J.: Prediction of BOD, COD, and total nitrogen concentrations in a typical urban river using a fluorescence excitation-emission matrix with PARAFAC and UV Absorption Indices, Sensors, 12, 972-986, doi:10.3390/s120100972, 2012.

Inamdar, S., Singh, S., Dutta, S., Levia, D., Mitchell, M., Scott, D., Bais, H., and McHale, P.: Fluorescence characteristics and sources of dissolved organic matter for stream water during storm events in a forested mid-Atlantic watershed, J. Geophys. Res.-Biogeo., 116, 1-23, doi:10.1029/2011JG001735, 2011.

Inamdar, S., Dhillon, G., Singh, S., Parr, T., and Qin, Z.: Particulate nitrogen exports in stream runoff exceed dissolved nitrogen forms during large tropical storms in a temperate, headwater, forested watershed, J. Geophys. Res.-Biogeo., 120, 1548-1566, doi:10.1002/2015JG002909, 2015.

IPCC: Summary for Policymakers, in Climate Change 2013 - The Physical Science Basis, edited by: Stocker, T. F., Qin, D., Plattner, G.-K., Tignor, M., Allen, S. K., Doschung, J., Nauels, A., Xia, Y., Bex, V., and Midgley, P. M., 1-30, Cambridge University Press, Cambridge, 2013.

Janeau, J.-L., Gillard, L.-C., Grellier, S., Jouquet, P., Le, T. P. Q., Luu, T. N. M., Ngo, Q. A., Orange, D., Pham, D. R., Tran, D. T., Tran, S. H., Trinh, A. D., Valentin, C., and RochelleNewall, E.: Soil erosion, dissolved organic carbon and nutrient losses under different land use systems in a small catchment in northern Vietnam, Agr. Water Manage., 146, 314-323, doi:10.1016/j.agwat.2014.09.006, 2014.

Jeong, J. J., Bartsch, S., Fleckenstein, J. H., Matzner, E., Tenhunen, J. D., Lee, S. D., Park, S. K., and Park, J. H.: Differential storm responses of dissolved and particulate organic carbon in a mountainous headwater stream, investigated by high-frequency, in situ optical measurements, J. Geophys. Res.-Biogeo., 117, 113, doi:10.1029/2012JG001999, 2012.

Johnson, M. S., Lehmann, J., Selva, E. C., Abdo, M., Riha, S., and Couto, E. G.: Organic carbon fluxes within and streamwater exports from headwater catchments in the southern Amazon, Hydrol. Process., 20, 2599-2614, doi:10.1002/hyp.6218, 2006.

Jung, B. J., Lee, H. J., Jeong, J. J., Owen, J., Kim, B., Meusburger, K., Alewell, C., Gebauer, G., Shope, C., and Park, J. H.: Storm pulses and varying sources of hydrologic carbon export from a mountainous watershed, J. Hydrol., 440-441, 90-101, doi:10.1016/j.jhydrol.2012.03.030, 2012.

Jung, B.-J., Jeanneau, L., Alewell, C., Kim, B., and Park, J.-H.: Downstream alteration of the composition and biodegradability of particulate organic carbon in a mountainous, mixed land-use watershed, Biogeochemistry, 122, 79-99, doi:10.1007/s10533014-0032-9, 2015.

Kalbitz, K., Solinger, S., Park, J.-H., Michalzik, B., and Matzner, E.: Controls on the dynamics of dissolved organic matter in soils: a review, Soil Sci., 165, 277-304, 2000.

Kao, S.-J. and Liu, K.-K.: Fluxes of dissolved and nonfossil particulate organic carbon from an Oceania small river (Lanyang Hsi) in Taiwan, Biogeochemistry, 39, 255-269, doi:10.1023/A:1005864605382, 1997.

Katsuyama, M. and Ohte, N.: Determining the sources of stormflow from the fluorescence properties of dissolved organic carbon in a forested headwater catchment, J. Hydrol., 268, 192-202, doi:10.1016/S0022-1694(02)00175-0, 2002.

Kaushal, S. S. and Lewis, W. M.: Patterns in the chemical fractionation of organic nitrogen in Rocky Mountain streams, Ecosystems, 6, 483-492, doi:10.1007/s10021-003-0175-3, 2003.

Kiikkilä, O., Smolander, A., and Kitunen, V.: Degradability, molecular weight and adsorption properties of Dissolved Organic Carbon and nitrogen leached from different types of decomposing litter, Plant Soil, 373, 787-798, doi:10.1007/s11104-013-18373, 2013.

Kim, S. J., Kim, J., and Kim, K.: Organic carbon efflux from a deciduous forest catchment in Korea, Biogeosciences, 7, 13231334, doi:10.5194/bg-7-1323-2010, 2010.

Korea forest research institute: Distribution of main tree species in South Korea - 1:5,000, Korea Forest Research Institute, available at: http://book.nifos.go.kr/ebook/Links/kfri/ 151027151648704_6_self (last access: 18 September 2016), 2013.

Lee, J.-Y., Kim, J.-K., Owen, J. S., Choi, Y., Shin, K., Jung, S., and Kim, B.: Variation in carbon and nitrogen stable isotopes in POM and zooplankton in a deep reservoir and relationship to hydrological characteristics, J. Freshwater Ecol., 28, 47-62, doi:10.1080/02705060.2012.689999, 2013.

Lloret, E., Dessert, C., Pastor, L., Lajeunesse, E., Crispi, O., Gaillardet, J., and Benedetti, M. F.: Dynamic of particulate and dissolved organic carbon in small volcanic mountainous tropical watersheds, Chem. Geol., 351, 229-244, doi:10.1016/j.chemgeo.2013.05.023, 2013.

MacDonald, J. A., Dise, N. B., Matzner, E., Armbruster, M., Gundersen, P., and Forsius, M.: Nitrogen input together with ecosystem nitrogen enrichment predict nitrate leaching from European forests, Glob. Change Biol., 8, 1028-1033, doi:10.1046/j.13652486.2002.00532.x, 2002. 
McGlynn, B. L. and McDonnell, J. J.: Role of discrete landscape units in controlling catchment dissolved organic carbon dynamics, Water Resour. Res., 39, SWC3-1-SWC3-18, doi:10.1029/2002WR001525, 2003.

Michalzik, B., Kalbitz, K., Park, J. H., Solinger, S., and Matzner, E.: Fluxes and concentrations of dissolved organic carbon and nitrogen - A synthesis for temperate forests, Biogeochemistry, 52, 173-205, doi:10.1023/A:1006441620810, 2001.

Moldan, F., Hruška, J., Evans, C. D., and Hauhs, M.: Experimental simulation of the effects of extreme climatic events on major ions, acidity and dissolved organic carbon leaching from a forested catchment, Gårdsjön, Sweden, Biogeochemistry, 107, 455-469, doi:10.1007/s10533-010-9567-6, 2012.

Park, J.-H., Duan, L., Kim, B., Mitchell, M. J., and Shibata, H.: Potential effects of climate change and variability on watershed biogeochemical processes and water quality in Northeast Asia, Environ. Int., 36, 212-225, doi:10.1016/j.envint.2009.10.008, 2010.

Pellerin, B. A., Kaushal, S. S., and McDowell, W. H.: Does anthropogenic nitrogen enrichment increase organic nitrogen concentrations in runoff from forested and human-dominated watersheds?, Ecosystems, 9, 852-864, doi:10.1007/s10021-006-00763, 2006.

Richey, J. E.: Global River Carbon Biogeochemistry, in Encyclopedia of Hydrological Sciences, John Wiley \& Sons, Ltd, Chichester, UK, 1-13, 2005.

Sanderman, J., Lohse, K. A., Baldock, J. A., and Amundson, R.: Linking soils and streams: Sources and chemistry of dissolved organic matter in a small coastal watershed, Water Resour. Res., 45, W03418, doi:10.1029/2008WR006977, 2009.

Seo, K.-H., Son, J.-H., and Lee, J.-Y.: A new look at Changma, Atmosphere (Basel), 21, 109-121 available at: http://www.koreascience.or.kr/article/ArticleFullRecord.jsp?cn= KSHHDL_2011_v21n1_109 (last access: 18 September 2016), 2011.
Singh, S., Inamdar, S., Mitchell, M., and McHale, P.: Seasonal pattern of dissolved organic matter (DOM) in watershed sources: influence of hydrologic flow paths and autumn leaf fall, Biogeochemistry, 118, 321-337, doi:10.1007/s10533-013-9934-1, 2014.

Singh, S., Inamdar, S., and Mitchell, M.: Changes in dissolved organic matter (DOM) amount and composition along nested headwater stream locations during baseflow and stormflow, Hydrol. Process., 29, 1505-1520, doi:10.1002/hyp.10286, 2015.

Smolander, A. and Kitunen, V.: Comparison of tree species effects on microbial $\mathrm{C}$ and $\mathrm{N}$ transformations and dissolved organic matter properties in the organic layer of boreal forests, Appl. Soil Ecol., 49, 224-233, doi:10.1016/j.apsoil.2011.05.002, 2011.

Trum, F., Titeux, H., Ranger, J., and Delvaux, B.: Influence of tree species on carbon and nitrogen transformation patterns in forest floor profiles, Ann. For. Sci., 68, 837-847, doi:10.1007/s13595011-0080-4, 2011.

von Schiller, D., Graeber, D., Ribot, M., Timoner, X., Acuña, V., Martí, E., Sabater, S., and Tockner, K.: Hydrological transitions drive dissolved organic matter quantity and composition in a temporary Mediterranean stream, Biogeochemistry, 123, 1-18, doi:10.1007/s10533-015-0077-4, 2015.

Yates, C. A. and Johnes, P. J.: Nitrogen speciation and phosphorus fractionation dynamics in a lowland Chalk catchment, Sci. Total Environ., 444, 466-479, doi:10.1016/j.scitotenv.2012.12.002, 2013.

Zsolnay, A., Baigar, E., Jimenez, M., Steinweg, B., and Saccomandi, F.: Differentiating with fluorescence spectroscopy the sources of dissolved organic matter in soils subjected to drying, Chemosphere, 38, 45-50, doi:10.1016/S0045-6535(98)00166-0, 1999. 